\title{
Gaming Simulation Models of Economic Entities
}

\author{
Ekaterina Gribanova \\ Tomsk State University of Control Systems and Radioelectronics \\ Tomsk, Russian Federation \\ katag@yandex.ru
}

\begin{abstract}
The study is dedicated to the implementation of simulation games, which are studied today as a useful instrument of interactive education. The article gives a view of the existing educational modeling tools. The description to the games "Deposits" and "Business-plan" is given. The first game is intended to study deposit operations, the participants should envision themselves in the role of depositors and demonstrate the ability to manage funds. In the second game, a company operation is studied. The games were implemented to be used during the educational process of "Basics of business" discipline, they were implemented in Excel.
\end{abstract}

Keywords—game; simulation model; business-plan; deposit

\section{INTRODUCTION}

Simulation modelling is a useful tool to analyze systems with randomized behavior without analytic solution [1]. This method allows to hold the research of real world objects in case if a real experiment is impossible, risky, requires large time and monetary expenditures. By holding multiple tests, it is possible to get statistical estimations, reveal influence of factors, estimate various variants aimed to optimize the system at the set target function.

The present method is successfully applied for educational software development and game implementation, as it is based on the reproduction of object's behavior in time and space with the help of program algorithms considering influence of random factors, which allows to model situations close to real ones.

Public interest to the improving the quality of higher education has been increasing now [2-3]. The games with simulation models in base are now a popular educational tool [4-12]. Many authors consider that such games increase educational motivation of students; they show the connection between abstract theoretical categories and real problems and also contribute to the active engagement of students into the educational process.

One of the areas, where such games can be successfully used is economics, because activity of an economics is connected with risks, decision-making in the range of uncertainty and should consider the existing laws of systems' behavior [9].

Among the existing games, we can note Stock Portfolio [10], intended for familiarization of students with a notion of portfolio optimization, Deal or not Deal [11], used on MBA course in Massachusetts technological institute that covered topics including statistics, decision analysis (probability, risk, utility), and optimization. The papers describe a spreadsheet implementation of these games. The study [12] describes a program which is intended for students' education on managing projects. The publication [4] describes Ja Titan and Market Hero to model economic process aimed to educate managers at the economic faculty.

In the paper [13] the authors describe a way to implement a simulation model of the game of roulette in spreadsheets and use it to analyze various strategies for the game in order to help students understand the probability concepts.

Some researchers also analyze the behavior of players in such TV game shows as: "Who Wants to be a Millionaire?", "Lingo", "Card Sharks" etc.

\section{TARGET SETTING}

The study is devoted to the implementation of imitation games to be used during the educational process of "Basics of business" discipline. This article will describe games "Deposits" and "Business-plan" [14] which consist of three basic components:

- players - students taking part in the game;

- simulation model;

- presenter - professor, acting for: game control, start of modelling stages, disclose of results. An interactive whiteboard and a projecting device are used to demonstrate results.

These games are developed using Excel spreadsheets [1518]. Spreadsheets are a widespread tool for a variety of tasks. We have Excel available on all university computers. The following useful features are available in that tool:

- a large number of functions;

- generating uniformly distributed pseudo-random numbers;

- integrated graphics;

- viewing, entering, and editing formulas in cell;

- macros and VBA programing.

Spreadsheet is an attractive platform for gaming, but it has some limitations:

- data storage is limited; 
- slow execution;

- complex algorithm are difficult to implement, Visual Basic doesn't support inheritance.

A benefit of embedding the game within a spreadsheet environment is the possibility of modifying the game and allowing users to change the rules and the numbers.

\section{THEORY}

\section{A. Game "Deposits"}

The participants of the game "Deposits" should envisage themselves in the role of depositors and demonstrate the ability to manage funds.

The task of players is to save money from inflation and get maximal profit. The team, that meets the challenges best of all, wins. In the course of the game, the students demonstrate theoretical knowledge in the area of financial mathematics: ways to grow interests, decrease risks, face such notions as inflation, diversification, and revenue position.

The game includes 5 stages; each of them corresponds to a calendar year. The groups are offered to deposit a sum (the value of 2 million is taken), choosing one or several banks. The team should make a decision on the base of analysis of the offered conditions: deposit type (ruble/currency), interest rate, interest charge (annual, semi-annual, quarterly, monthly), insurance of deposits (yes/no), capitalization (yes/no).

When the teams disclose their decisions, the first modeling stage is started. The following actions are held here:

- An event of bank closing is modelled;

- Inflation value, interest rate and dollar exchange rate are updated;

- The resulting deposit sum is calculated.

The teams are told the values of funds which they get in the result of the first stage. On the base of this information the participants redistribute the existing funds between the banks.

Initially, the value of bank operation flag is set equal to 1, which means that the bank is open (zero value means the bank is closed). In the succeeding periods, the value is determined according to the algorithm of modeling a simple event on a set probability value:

$$
\text { if } p<z \text { then open }=0 \text { else } \text { open }=1 \text {, }
$$

where $p$ - probability of bank closing;

$z$-random value with a uniform distribution on the interval $(0,1)$;

open - value of bank operation flag.

The macro generates random numbers from the sheet. This data is hidden for players.
Value in the bank account is calculated depending on the growth method (simple/complex), bank closing event time, participation of the bank in insurance system (coverage is limited to 1400000 rubles per account). This value is also corrected according to the inflation rate.

The final investment, using simple interest formula:

$$
I=I_{0} \cdot(1+j \cdot m)
$$

where $I$ - value in the bank account at the end of year;

$I_{0}$ - value in the bank account at the beginning of the year;

$j$ - interest rate;

$m$ - number of periods in a given year.

If interest rate is complex then:

$$
I=I_{0} \cdot(1+j)^{\mathrm{m}} \cdot
$$

The forecast for dollar value has been developed using data from 2009 to 2014.

It was decided to use autoregression model for dollar exchange rate estimation [19]:

$$
y_{i}=\theta_{0}+\theta_{1} y_{i-1}+u_{l},
$$

where $i=1 . . n-$ number of observations;

$y_{i}$ - endogenous variable;

$\mathrm{y}_{\mathrm{i}-1}-$ exogenous variable;

$\theta_{0}, \theta_{1^{-}}$estimations of parameters of regression affine function (a least squares method is used to evaluate these parameters);

$\mathrm{u}$ - random remainder.

After unknown parameters had been determined by the method of minimal squares we obtained the model below:

$$
\text { dollar }_{i}=23,881+2,9991 \cdot \text { dollar }_{i-1},
$$

where dollar - dollar exchange rate at period $i$.

The regression function for dollar exchange rate forecasting changes over time.

Participanfs $+q_{a n}=\chi$ choose (1s)uch 16 anks as Sberbank, Gazprombank, Bank24.ru, BankVTB. The deposit interest rate is calculated using historical data from 2011 to 2015.

The players do not know the future value of a dollar exchange rate and the future value of a deposit interest rate.

The inflation values from 2011 to 2015 were taken to determinate real revenue.

The game is implemented in Excel. Fig.1 shows an example of team work result after the first stage (the team has two different bank accounts). 


\begin{tabular}{|c|c|c|c|}
\hline \multicolumn{4}{|c|}{ team 1} \\
\hline Bank 2 & & Bank 4 & \\
\hline Deposit account: & & Deposit account: & \\
\hline deposit interest rate & $1,94 \%$ & deposit interest rate & $12,50 \%$ \\
\hline deposit sum, rubles & 1350000,00 & deposit sum, rubles & 843750,00 \\
\hline New deposit: & & New deposit: & \\
\hline deposit interest rate & $1,37 \%$ & deposit interest rate & $10,00 \%$ \\
\hline put money, rubles & & put money, rubles & \\
\hline put money, dollars & & put money, dollars & \\
\hline Cash, rubles & 2193750,00 & четом 1 1म & 5 \\
\hline Deposit sum, rubles & - & & \\
\hline
\end{tabular}

Fig. 1. Result of the first game stage

Students should be given a time limit to make a decision. A game duration is equal to the duration of a lesson.

\section{B. Game "Business-plan"}

In the course of the game "Business-plan", groups of participants should make decisions about location of business, purchase of materials and equipment, choice of personnel and sale prices. After determination of all parameters, the demand and determination of the financial result are modelled. The team, that gets the highest profit, wins. The game studies the following economic notions: law of demand, variable and constant costs, risk estimation, optimization of costs, taxation system, etc.

One game variant offers to open a kiosk offering a service of document copying. The participants should make decisions regarding the following positions:

- Choice of location. Five shops are offered for location, each of them is characterized by the size of rental fee and publicity (table 1), defined with the help of an Internet source. The total area of shop is 40 square meters.

- Choice of personnel. It is necessary to choose one kiosk employee of the three offered candidates. The employee's qualification reduces with the reduction of his salary requirements [20].

- Choice of equipment and materials. Using the Internet, the participants carry out a search of necessary equipment and materials, calculate variable and constant costs. They also need to define the size of the stamp duty for the company registration.

- Choice of price. Finally, it is necessary to make a decision on the offered service price considering prices of the competitors.

This way, model's input information is formed:

- constant costs;

- variable costs;

- publicity of the chosen place;

- qualification coefficient of the chosen employee;

- competitors' average price;
- sales price.

The qualification coefficient takes values from 0 to 1 .

TABLE I. SHOP DESCRIPTIONS

\begin{tabular}{|l|c|c|}
\hline \multicolumn{1}{|c|}{ Name } & $\begin{array}{c}\text { Publicity, people } \\
\text { per day }\end{array}$ & $\begin{array}{c}\text { Monthly rental fee, } \\
\text { rubles per square } \\
\text { meter }\end{array}$ \\
\hline Bottom & 4000 & 1500 \\
\hline Dlade & 2500 & 700 \\
\hline Bystronom & 7000 & 600 \\
\hline Rainbow of taste & 2900 & 550 \\
\hline Basket & 2100 & 500 \\
\hline
\end{tabular}

The value of the monthly income is defined as the remainder of revenues and costs:

$$
\text { profit=pages } \cdot \text { price-costs, }
$$

where profit - monthly income;

pages - number of pages ordered by each client;

price - price per page;

costs - constant and variable costs.

To determine the volume of sales, competitors' average price is used. It is supposed, that when the participants chose the price, the number of clients will be a per cent of location publicity. At the increase in times, the number of clients will be equal to zero. A linear additive model is used to predict the volume of sales (fig.2).

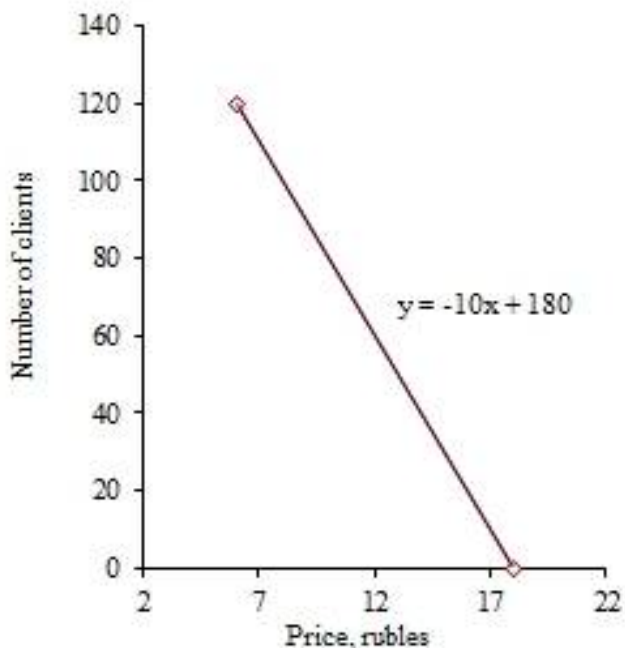

Fig. 2. The function of sales (first shop)

So, the daily number of clients is calculated by the formula:

$$
\text { demand }=\text { proff } \cdot\left(\theta_{0}+\theta_{1} \cdot \text { price_m+u } m\right. \text {, }
$$


where demand - daily number of clients;

proff - qualification coefficient of the chosen employee;

price_m-competitors' average price;

$u$ - random value with a normal distribution law and zero mathematic expectation (mean-square deviation is taken as equal to 3 );

$\theta_{0}, \theta_{1^{-}}$estimations of parameters of regression affine function. Negative value tells about drop of demand due to price increase.

A standard normal generated using the following method: add 12 uniform random variables and subtract 6 . The normalized values are multiplied by the standard deviation.

Finally, the number of pages ordered by each client is a random value. The model uses an exponential with an average value (considered equal to 10 ). The daily number of pages is calculated by the formula:

$$
\text { pages }=\sum \text {-mpage } \cdot \ln (z)
$$

where pages - daily number of pages ordered by clients; clients;

mpage - average value of number of pages ordered by each $(0,1)$.

$z$-random value with a uniform distribution on the interval

The modelling is carried out during twelve months.

The team, that gets maximal profit for a year, wins.

Fig. 3 shows an example of team work result after the first stage (virtual month). The qualification coefficient for the chosen employee (№2) is taken as equal to 2 . The players may choose another value of the sale price.

\begin{tabular}{|c|c|c|c|}
\hline \multicolumn{2}{|c|}{1 month } & \multirow[b]{2}{*}{ rubles } & \\
\hline Revenues & 247632,00 & & \\
\hline Costs & 235376,00 & rubles & \\
\hline \multirow[t]{2}{*}{ Income } & 12256,00 & rubles & \\
\hline & Candidates & & \\
\hline № & Name Surname & Age, working experience & Monthly salary, rubles \\
\hline 1 & Ivanov Ivan & 19, none (student) & 14000 \\
\hline 2 & Petrov Pert & 25,3 years & 20000 \\
\hline \multirow[t]{4}{*}{3} & Sidorov Anton & 27 , none & 19000 \\
\hline & Select the employee & 2 & \\
\hline & Monthly salary & 20000 & \\
\hline & Sales price, rubles & 6,00 & \\
\hline
\end{tabular}

Fig. 3. Result of the first game stage (virtual month)

Other game variants are also studied: sale of coffee, flowers, newspapers etc.

\section{CONCLUSIONS}

Interactive simulations of economic processes are able to fairly improve the level of students' perception of material and quicken interest in the studied topic. The article studies the existing imitation applications and gives the description of the implemented games "Deposits" and "Business-plan". At the implementation of games, the methods of simulation modelling and regression analysis were used. With the help of these games, the participants can feel themselves as investors, who need to properly manage funds or a businessman, who needs to make decisions regarding business organization. The games can be used in teaching activities in the economics and finance disciplines. They also demonstrate the use of modeling in the learning process.

\section{REFERENCES}

[1] Y.N.Pavlovsky, "Simulation modeling". M.: Academy, 2008.

[2] N. Chistyakova, M. Semenova, V. Spitsin, P. Paquet, "Problems of educational process development and labor market needs analysis in Russia”, Procedia - Social and Behavioral Sciences, vol. 166, 2015, pp.

[3] M.V. Grigoryeva, T.S. Kust, E.B. Gribanova, "Research activities of students and information technology as a method to support interdisciplinary teaching in training process of technical university", Information Technologies in Science, Management, Social Sphere and Medicine, 2016, pp. 322-327.

[4] J.A. Peterkova, Z. Wozniakova, "The best practice in teaching process by using managerial simulation games", Procedia - Social and Behavioral Sciences, vol. 174, 2015, pp. 3862-3867.

[5] J. Caballero-Hernandez, M. Palomo-Duarte, J.M. Dodero, "Skill assesment in learning experiences based on serious games: A systematic maping study", Computers \& Education, vol. 113, 2017, pp. 42-60.

[6] J. Parong, R.E. Mayer, L. Fiorella, A. MacNamara, B.D. Homer, J.L. Plass, "Learning executive function skills by playing focused video games", Contemporary Educational Psychology, vol.51, 2017, pp. 141151.

[7] C. Kazimoglu, M. Kiernan, L. Mackinnon, "A serious game for developing computational thinking and learning introductory computer programming", Procedia - Social and Behavioral Sciences, vol. 47, 2012, pp. 1991-1999.

[8] W. Seng, M.H. Yatim, "Computer game as a learning and teaching tool for object-oriented programming in higher education institution", Procedia - Social and Behavioral Sciences, vol. 123, 2014, pp. 215-224.

[9] E. Inas, L. Cecilia, "An Investigation of the use of simulation tools in management education", Proceedings of the 2012 Winter Simulation Conference, 2012, pp. 1502-1515.

[10] V. Rene, "The Stock Portfolio Game", Informs Transactions on Education, vol.1, 2007, pp. 41-48

[11] C. Timothy, "Deal or No Deal: A Spreadsheet Game to Introduce Decision Making Under Uncertainty", Informs Transactions on Education, vol.1, 2013, pp. 53-60.

[12] L. Wee-Leong, "Spreadsheet based experiential learning environment for project management", Proceedings of the 2011 Winter Simulation Conference, 2011, pp. 3882-3892.

[13] K.C. Seal, Z.H. Przasnyski, "Illustrating probability through roulette: a spreadsheet simulation model", Spreadsheets in education, vol. 2, 2005, pp. 1-22.

[14] E.B. Gribanova, "Gaming simulation economic models", Dynamic of systems, mechanisms and machines, vol.3, no.1, pp. 320-323.

[15] A.F. Seila, "Spreadsheet Simulation", Proceedings of the 2006 Winter Simulation Conference, Monterey, 2006, pp. 11-18.

[16] J.R. Evans, "Spreadsheets as a Tool for Teaching Simulation", Informs Transactions on Educations, vol.1, 2000, pp. 27-37. 
[17] A. Thomas, Jr. Grossman, "Teachers' Forum: Spreadsheet Modeling and Simulation Improves Understanding of Queues", Interfaces 29:3, pp. 88-103.

[18] J. Pecherska, Y. Merkuryev, "Teaching simulation with spreadsheets", Procedings $19^{\text {th }}$ European Conferencr on Modeling and Simulation, 2005 , pp. 1-6.

[19] C. Dougherty, "Introduction to Econometrics", Oxford University Press, 2000.

[20] V. Spitsin, A. Mikhalchuk, L. Spitsina, E. Akerman, T. Nataliya, A. Semes, D. Novoseltseva, "Comparative analysis of salary, labor intensity and payroll-output ratio of foreign and domestic firms: case russian vehicle industry", Proceedings of the 2015 International Conference on Education Reform and Modern Management, 2015, pp. 371-374. 